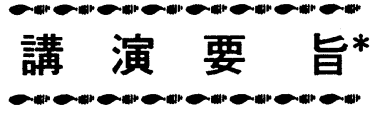

\section{和歌山県におけるヒメハナ カメムシ類の発生}

\author{
森下正彦・矢野貞彦 \\ （和歌山県農業試験場）
}

\begin{abstract}
ミナミキイロアザミゥマは，関東以西において果菜 類を中心に大きな被害を及ぼし，重要害虫の一つであ るが、ヒメハナカメムシがその天敵として有効である ことが明らかにされてきた（永井，1993など）。現在， わが国でヒメハナカメムシOrius属が 6 種類知られて いるか（安永・柏尾, 1993), 発生の地域性や施設へ の適応性などは明らかにされていない。そこで, 本県 におけるヒメハナカメムシ類の発生消長を調査した。
\end{abstract}

\section{調查方法}

調査は1993年と1994年の 5 〜0月に行った。シロッ メクサは捕蜶によるスィーピング法で，スィートコー ン，イネ，セイタカアワダチソウは捕蛧の中で花を 吒いて，ナスでは直接吸䗆で成虫を採集した。標本 をエチルアルコールで固定後, 実体顕徽鏡下で雄の腹 部末端節を切除し, 交尾器 (左把握器) により種類を 判定した。

\section{結果及び考察}

本県ではナミヒメ八ナカメムシ (Orius sauteri, 以 下「ナミ」と略す）とタイリクヒメハナカメムシ（O. similis, 以下「タイリク」と略す）の二種が確認され た。

貴志川町では 5 月からシロッメクサで発生し， 5 〜 8 月にシロッメクサから採集された個体の $90 \%$ 以上を ナミが占めた。シロッメクサは春から初夏にかけて開 花数が多かったが， 7 月下旬以降は乾燥とイネ科雑草 の繁茂により草勢が抑兄られ，開花数が少なくなった。 そのため餌となるアザミウマ類が咸少し，ヒメ八ナカ メムシ類の個体数が減少したと考えられた。また10月 にセイタカアワダチソウで採集されたものもナミが優 占した。しかし，ハウス栽培のナスでは $7 〜 8$ 月にタ イリクの比率が $60 \sim 80 \%$ と高かった。

一方，御坊市と印南町では，6月にシロッメクサで ナミが優占したのは貴志川町と同じであったが，10月 にセイタカアワダチンウで採集されたものはタイリク が優占し，地域差が見られた。

\section{熱帯水田系におけるサンカメ イガとシロメイガの発生 パターンの比較}

\author{
沢田裕一 \\ （滋賀県立短期大学）
}

熱帯に生息する稲の食入性害虫として, サンカメイ ガ, イネシロオオメイガ (以下シロメイガと略), = カメイガ, ネッタイメイガ (以上メイガ科), ダイメ イガ (ヨトウガ科) などが知られているが，中でもサ ンカメイガとシロメイガの被害が大きい。サンカメイ ガはトビイロウンカと並ぶ熱帯の最重要稲作害虫であ る。他方, シロメイガは, 第二次大戦以前の欧米の植 民地時代には幾度もの大発生とそれに伴ら飢饉を引き 起こし，熱帯了ジアを代表する主要害虫とされていた が (Van der Goot 1925,1948など)，その後数十年 間に亘って発生量は少なく，いわば害虫として忘れら れた存在であった（Kalshoven 1981）。ところが，19 88年以降，インドネシアのジャワ島でシロメイガが大 発生し,この地域の米生産に深刻な打撃を与兄ている （平野・沢田 1992）。

東南アジア有数の穀倉地带である西ジャワ州北部平 野46万ヘクタールの水田地帯に16台の予察灯を設置し, 3 年間に亘ってサンカメイガとシロメイガの発生状況 を調査した結果, 両種の地域的季節的発生パターンに 顕著な相違の存在することが判った。すなわち，1） サンカメイガが平野部でも内陸部でも多発生するのに 対し, シロメイガの多発地带は, 平野部の同期栽培地 帯（乾季がはっきりして，乾季に休閑期が設定される） に限定される，2）サンカメイガの発生量は，休閑期 後の第一作期で少なく，それに続く第二作期で增加す るのに対し，シロメイガでは，第一作期で大きく第二 作期で減少する。

こらした両種の発生パターンの相違には, シロメイ ガが休閑期（乾季）に稲の刈り株内で幼虫休眠するこ と，及び，卵寄生蜂などの天敵生物の作用が関係して いることが指摘された。すなわち，休閑期を休眠状態 で乗り越えたシロメイガは，他の昆䖨に比べいち早 く第一作期の初期水田に出現し, 天敵密度の低い好適 な条件下で急速に個体数を增するのと考兄られる。実 際, シロメイガの卵の被寄生率は, 第二作期より休閑 期後の第一作期の方が低いこと，また，同一作期内で は初期の被寄生率の方が低いことが示された。

*第77回研究会発表会は，1995年 5 月19日に三重県津庁舎において開催された。 


\section{ナチュラリス Lのウンカ・ \\ ヨコバイ類に対する防除効果}

\author{
伊藤啓司 \\ （愛知県農業総合試験場）
}

水稲栽培においては, 環境保全やより安全な農産物 を供給するため, 堿農薬防除体系をさらに推進する必 要がある。昆虫病原菌を利用した微生物的防除はその. 有効な手段の一つである。

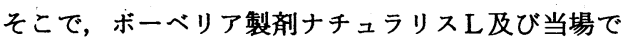
分離したBeauveria bassiana（保存菌番号 : B-NL-001） のウンカ・ヨコバイ類に対する防除効果を検討した。

\section{試験方法}

試験は，場内の 5 月26日植えの「あいちのかおり」 を使用し， $50 \mathrm{~m}^{2} 1$ 区制で実施した。薬凧処理は，7 月14日と21日に実施し，ナチュラリス Lは500倍，B$\mathrm{NL}-001$ は $1 \times 10^{7}$ 分生子 $/ \mathrm{ml}$, 対照薬剂として 7 月

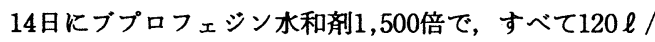
$10 \mathrm{a}$ 散布した。

セシロウンカ, ヒメトビウンカ及びッマグロヨコバ イの調査は, 10株の払い落としを各区 3 か所実施した。

1994年はトビイロウンカの飛来がほとんどなかった ので, 各区 2 か所 12 株に寒冷紗を被覆し, トビイロウ ンカ中龄奻虫を株当たり 2 頭（1 寒冷紗の中に24頭）

放飼した。放飼35日後の 8 月18日に寒冷紗内全株の寄 生幼虫数を調査した。

\section{結果及び考寮}

セシロウンカのナチュラリス L及びB-NL-001の散 布14日後における補正密度指数は, 対照薬昘のアプロー ド水和剤1,500倍散布の7.4（散布21日後）に比べやや 低いものの31.2及び23.4と防除効果が認められた。そ れに対し，ヒメトビウンカ及びッマグロヨコバイでは， 防除効果が低かった。これは，セジロウンカの生育ス テーシの揃いがよく，幼虫を対象に適期防除できたの に対し，ヒメトビウンカ及びッマグロヨコバイでは， 生育ステージがばらついたためと考えられる。

トビイロウンカは, 寒冷紗内の全寄生幼虫数を調査

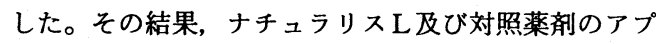
ロード散布区では, 寄生虫数が 0 頭となり, 極めて防 除効果が高かったが，B-NL-001は効果が劣った。こ の原因は, 散布時の気温が高く, B-NL-001の感染力 が低下したためと思われる。

\section{ミカンハダニの主要ダニ剤に 対する薬剤抵抗性の発達}

\author{
大橋弘和・中 一晃 \\ （和歌山県果樹園芸試験場）
}

主要殺ダニ剤に対するミカンハダニの防除効果が和 歌山県の主なカンキツ産地で低下し，大きな問題となっ てきている。そこで, フェンピロキシメート斉, ピリ ダベン剂, テブフェンピラド斉（以下，主力 3 剂と称 す）を中心に薬剤抵抗性の発達状況を調査した。

1992，1993年に有田地域の 5 園を定点とし，フェン ピロキシメート剤, ピリダベン阂に対し薬剤抵抗性検 定を行った。検定はリーフディスク法とし，2 日間産 卵させ,さらに 1 日置いた後の卵を10秒間浸漬処理し その後にふ化状況を調查した。検定は実用の $1 / 3$ 濃 度と $1 / 10$ 濃度で行った。その結果，1992年は両剂と も高い感受性を示したが，1993年には 1 園でフェンピ ロキシメート斉に対し感受性の低下が認められた。本 剂は1991年から使用され，比較的早く抵抗性が発達し たと考えられた。

1994年に31園よりミカンハダ二の寄生虫枝を採取し， リーフディスク法で抵抗性検定を行った。フェンピロ キシメート剂は接種直後の雌成虫に薬液を散布し（薬 液付着量 $: 6.3 \mathrm{mg} / \mathrm{cm}^{2}$ )，2 日後に生死を判定した。 ピリダベン剂, テブフェンピラド剤，B P P S 剂, フェ ンプロパトリン剤+アセフェート剤, ケルセン刻は,

接種 2 日後の卵に対し10秒間浸漬処理した。検定は実 用濃度とその $1 / 3$ 濃度及び $1 / 10$ 濃度とした。

その結果, 主力 3 剂に対する薬剤抵抗性は海草及び 有田地区を中心に広い範囲で多くの園地に認められ, 著しく抵抗性の発達した園もあった。これに対し, 西 牟婁地区では主力 3 昘に対する薬剤抵抗性の発達は認 められなかった。また, 主力 3 㶡の補正殺虫率または 補正殺卵率との間には相互に有意な正の相関が認めら れ, 正の交差抵抗性の関係が同われた。主力 3 剂に対 する薬㶡抵抗性の発達が早かったのは, 交差抵抗性の 関係によると考えられた。

B P P S 剂は感受性, フェンプロパトリン剂十アセ フェート剤およびケルセン剤は薬㶡抵抗性を広域で示 した。主力 3 剤と B P P S 剂, フェンプロパトリン剤 +アセフェート剤, ケルセン剂の各薬凧間には有意な 相関は認められなかった。 


\section{ミカンキイロアザミウマの ブドウ，モモにおける奇生}

\author{
増井伸一・土屋雅利・多々良明夫*
}

（静岡県柑橘試験場・*静岡県西部病害虫防除所）

1994年 4 月中旬に浜松市で施設栽培されているブト ウ ‘ピオーネ’で幼果期の果粒に黒点ができ，これを 中心として周囲数 $\mathrm{mm} \sim 10 \mathrm{~mm}$ が不定形に白く変色す る白ぶくれ症状が発生した。被害確認直後に行った施 設内の調査では, 雑草や自家用栽培野菜にミカンキイ ロアザミウマの寄生がみられ，栽培棚下（地上 $150 \mathrm{~cm}$ ) に設置した黄色平板粘着トラップには本種のみが捕獲 された。そこで, 接種による被害再現試験を行った。 'ピオーネ' 無加温栽培ハウス（3月13日被覆，5月11 日開花始め，7年生樹）で，5月20日から 6 月17日まで 1 週間間隔で毎回 5 果房を供試し，1果房あたり20頭 のミカンキイロアザミウマ雌成虫を接種した。供試果 房は袋掛けし，紙袋の全端をビニルテープでとめ果軸 と袋の間吵をワセリンでふさいで接種虫の逃亡を防ぎ， 接種 1 週間後にカルタップ500ppm溶液で果房を洗浄 して接種虫を回収した。この結果, 果粒発育初期の 5 月20日及び27日に接種した果房で果粒に白ぶくれ症状 が再現され，6月 3 日以降の接種果房ではこの症状が 発生しなかった。本症状は本種と同属のヒラズハナア ザミウマの産卵により発生するトマトの白ぶくれ症状 と酷似していることから，開花始めから約20日間に本 種に産卵された場合に症状が発生すると考えられた。

また, 1994年に浜松市内の露地及び施設栽培のモモ に本種の寄生が確認された。露地で 6 月24日に行った 調査では果実への成幼虫の寄生は着色直前の “白鳳” と比べ着色後の ‘武井白鳳” ‘ちよひめ’で多かっ た。“白鳳”果実について 1 週間間隔で収檴まで40果 に寄生する成幼虫数を調査し，毎回10果を採取し洗浄

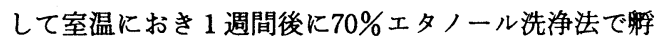
化幼虫数を調査した。新梢はカルタップ500ppm溶液 で洗浄して寄生している成幼虫数を調査した。この結 果, “白鳳”果実では着色期から収穫期にかけて成幼 虫の寄生が多く, 成虫の寄生は 7 月 1 日の着色期に, 幼虫の寄生は 7 月15日の収穫期に最も多かった。また， 餒化幼虫数は 7 月 1 日に採取した果実で最も多かった。 寄生樹の熟果では本種の加害の特徵であるかすり状の 症状がみられた。本種は新梢にも奇生がみられたが被 害は確認されなかった。

\section{バラにおけるミカンキイロ \\ アザミウマの被害と防除薬荗}

\author{
中込暉雄・平野哲司 \\ （愛知県農業総合試験場）
}

近年, 新発生害虫であるミカンキイロアザミウマ (Frankliniella occidentalis) がバラに発生し, 品質を 大きく低下させている。

そこで，バラの花（つぼみを含む）における本虫の 生息数と有効薬剤の選抜及びほ場における薬剤の効果 と薬害について検討したのでその概要を報告する。

\section{試験方法}

花の中の虫数把握は開花程度別（花の切り前, 誠文 堂新興社）に採集した花を70\%アルコールに浸漬した 場合と分解した場合の虫数を比較した。

有効薬剤の選抜は満開の花を各薬剤の所定濃度に 2 〜3秒間浸漬し， 5 日後に水を張った白色バット内で 花弁を分解して生虫数を調査した。

ほ場における効果は定植 3 年目のロックウール栽培 （品種：ティネケ）において，6月下旬から 7 月上旬 に 7 日間隔で 3 回薬剤散布した。調査は薬㶡の各散布 前に花を採取し，アルコール中で幼虫数を，また採集 散布 7 日後には花の被害を調査した。

\section{結果および考察}

1）本虫の生息場所であるバラの花（つぼみを含む） の中の虫数を正確に把握するため, 開花程度別の虫数 を調査した。その結果, 切り前 1 では花の中には侵入 虫は認められず，切り前 3 では成虫がわずかに，切り 前 6 では成虫と幼虫が検出された。このことから, 薬 昘の効果試験等で花中の虫数を把握する場合, 切り前 6 以上では花弁の分解が必要と考える。

2）薬液浸漬試験により効果の高いと考えられる薬 剤（生虫の認められなかった薬剤）はベンソエピン, アクリナトリン, フルバリネート, カルタップ, チオ シクラム, フルフェノクスロンであった。いずれの薬 剤も成虫に対する効果は劣る。花弁には薬害は認めら れなかった。

3）法場試験の結果を 3 回散布 7 日後の虫数と被害 花率で判定すると, アセフェート剂は効果も高く薬害 も認められなかったが，スルプロホス斉，プロチオホ ス剤, プロフェノホス剤はある程度の効果は認められ るものの, いずれも葉に薬害が発生し, チオシクラム 同は効果はやや劣るものの薬害は認められなかった。 


\section{寒冷紗被覆によるマメ八 モグリバエの防除}

\author{
市川耕治・大野 徹 \\ （愛知県農業総合試験場）
}

愛知県では1991年の春ごろからキク，トマトを中心 にマメハモグリバエによる被害が多発している。本種 は寄種範囲が極めて広いら文，多くの薬㶡に対して感 受性が低く，また，登録薬剤がほとんどないため難防 除害虫となっている。そこで薬阂以外の防除法として， 寒冷秒被覆による本種の侵入防除効果について検討し たので, その概要を報告する。

\section{試験方法}

試験は農総試園芸研究所内ガラス室において実施し た。試験装置は, 幅 $50 \mathrm{~cm}$, 高さ $90 \mathrm{~cm}$, 奥行き $70 \mathrm{~cm}$ の小型パイプ枠（小型ハウス）を用い，その前面及び 後面の中央部に供試寒冷紗を, それ以外の部分には一 般農業用ビニールを被覆した。試験は 3 回に分けて行 い, 寒冷紗は, 1 回目に透明及び銀色の寒冷紗で目合 いの異なる 8 種を, 2 回目にアルミ蒸着ネット 4 種と， 毛羽立ちの有無及び目合いの異なる 4 種を，3 回目に 目合いを統一し色の異なる 8 種を供試した。各小型八 ウスにはミニトマトあるいはナスを入れ，7 日後，14 日後に調査をした。調査は成虫食害痕数, 幼虫数, 脱 出痕数と, 小型ハウス内の天井下 $15 \mathrm{~cm}$ の位置に取り 付けた $10 \mathrm{~cm}$ 角の黄色粘着トラップの表裏に誘殺され る成虫数を調べた。

\section{結果及び考察}

寒冷紗被覆による本種の侵入防止を検討した結果, 目合い $1.0 \mathrm{~mm}$ 以下の寒冷紗は, 本種の侵入防止効果 が高いことが判明した。なお, 目合い $2.0 \mathrm{~mm}$ の寒冷 紗でもある程度侵入数を減らすことができると思われ た。また, 目合いが大きくても毛羽立ちのある寒冷紗 の方が，本種の侵入数は少ない傾向がみられた。アル ミ蒸着ネットでは, 目合いの小さいアルミ300番で効 果は高く, 粘着トラップによる成虫誘殺数は無被覆の 1/5であった。色については, 銀, 黒, 青, 緑, 赤 の 5 色の寒冷紗で, 対照の透明寒冷紗とほぼ同等の侵 入防止効果が認められた。なかでも青色の寒冷紗は成 虫侵入数及び成虫食害痕数が少なかった。また，オレ ンジ及び黄色では侵入防止効果は低かった。 以上の結果より, 寒冷秒被覆は本種の侵入防止に大 きな効果があり，省力的な防除法であることが判った。

\section{ガーベラのハウス栽培におけ る紫外線除去フィルム利用に よるマメハモグリバエの防除 井口雅裕・矢野貞彦・森下正彦 宮本純子 （和歌山県農業試験場）}

前報（第36号）では，エンドウのハウス栽培での外 張り資材として，390nm以下の波長の光を透過しない 紫外線防除フィルム（UVA）を用いるとナモグリバ エの発生を抑制する効果のあることを報告した。今回 は, ガーベラのハウス栽培において, 同じUVAを用 いてマメハモグリバエに対する発生抑制効果を検討し た。

\section{試験方法}

試験は御坊市名田町の農家ハウスで, 平成 5 年10月 20 日から平成 6 年 6 月 28 日まで行った。品種は ‘パソ’ で, 定植は平成 4 年 5 月 20 日であった。平成 5 年 10 月 30 日に，隣接した 2 棟のハウスについて，一方はU V Aに，他方は一般農ビ（CA）に張り替えた。

10月20日に無被害葉 1 株 1 葉, 40株計40葉をマーク し, 以後 $6 \sim 32$ 日毎に幼虫による食痕数を調査した。 調查葉を古くなると再び無被害葉に同様にマークし, 調査を継続した。また, 両区ハウスに 1 基ずつ黄色粘 着トラップ（I T シート, $20 \mathrm{~cm} \times 20 \mathrm{~cm}$ ) を地上 $50 \mathrm{~cm}$ 設置し, 誘殺される成虫数を半旬毎に調査し た。

\section{結果および考察}

調査開始時はすでにマメハモグリバエが多発してお り，UVA被覆後も密度抑制効果は認められなかった。 12月下旬以降, 両区ハウスとも発生が減少し, 幼虫 の食痕は 2 月 9 日以後認められなくなった。

黄色粘着トラップによる成虫誘殺は両区とも 4 月中 旬以降に漸增したが，UVA区の誘殺数は 5 月下旬ま でC A区の 1 ／ 2 以下であった。ハウス側面の開口率 が高まった 6 月以降は, UVA区においても増加し, 両区の差がみられなくなった。

幼虫の食痕は両区とも5月11日調査時から確認され たが，UVA区の食痕数は 6 月 21 日調査時までCA区 と比べて明らかに少なく，1／8以下であった。その 後はUVA区も増加し, 両区の差がみられなくなった。

以上のことから，UVA被覆は初期発生時の成虫の 侵入防止に効果があり，6月中旬までの奻虫の被害抑 制効果が期待できる。しかし，一度ハウス内に成虫が 侵入すると, 密度抑制効果はないと考えられた。 


\section{整枝作業によるナス薬唷散布 時の人体被曝量の低減}

\author{
谷川元一・国本佳範・浅野 亨 \\ 稲村和子*・井上雅央 \\ （奈良県農業試験場, *奈良県農政課)
}

夏秋ナスの生産地では, 病虫害防除のために多数回 の薬剂散布が行われており, 散布者は大量の人体被曝 を受けている。今回, 散布者の人体被嚗量を低减する 目的で，ナスの整枝作業が人体被曝量に及ぼす影響を 調査したので報告する。

試験方法: 試験は, 1993年10月に北葛城郡広陵町の V 字整枝法および磯城郡田原本町のU字型整枝法で管理 されたナス畕場（それぞれ，V字型整枝固およびU字 型整枝固, 品種：千両 2 号, 樹高：約 $2 \mathrm{~m}$ ) で実施し た。両煵場とも，生産者によって慣行的に管理されて いる区（慣行管理区）と，主枝から通路側に突き出て いる茎葉を整枝した区を設けた。なお，整枝作業によっ て収量が低下しないよ5に，花芽・幼果の付いている 茎葉については, 切断・除去するのではなく誘引する のみに止めた。

薬剤として，6\%シペルメトリン乳剤の 1000 倍希釈 液を供試し, 環状10頭ロノズルと動力噴霧機を用いて 毎分 $4 \ell$ の流量で散布した。散布者は利き腕が右の男 性 3 名で，前進散布法を用いて散布した。人体被曝量 の測定は一昨年報告した方法に従った。全身 9 力所に 直径 $6 \mathrm{~cm}$ の滤紙を装着し, 通路を往復して散布した 後, 濾紙を回収した。薬剤はアセトンで抽出後, ガス クロマトグラフで測定した。人体被曝量は散布距離 $100 \mathrm{~m}$ 当たり濾紙に付着した薬剂量 $(\mu \mathrm{g})$ で表した。 結果および考察：V字型整枝圃では，慣行管理区の場 合, 左右の膝上部は $5 \mu \mathrm{g}$ 末満であったが, 上半身の 頭上部, マスク, 胸部, 左右の前腕部, および左右の 上背上部は $12.4 \sim 56.6 \mu \mathrm{g}$ であった。しかし, 整枝作 業によって被曝量は全部位で減少し, 特に, 被曝量の 多かった上半身部位は1.2 $6.7 \mu \mathrm{g}$ と大幅に隇少した。

U字型整枝圃では, 慣行管理区の場合, 被曝量は $1.2 \sim 39.7 \mu \mathrm{g}$ であった。しかし, 整枝作業により0.1 $\sim 2.5 \mu \mathrm{g}$ と大幅に減少した。

以上の結果から, 夏秋ナスの栽培は，8月以降，葉 面積および花芽を確保するために整枝の栽培管理が低 下するが，ナスの薬剤散布時における人体被曝量を軽 減するためには，通路側に突き出ている茎葉を整枝す ることが有効であることがわかった。

\section{キク白さび病の発生状況と 高温による防除

\author{
杉村輝彦・萩原敏弘・岡山健夫 \\ 松谷幸子 \\ （奈良県農業試験場）
}

キク白さび病は，商品価値を著しく低下させるので キクの重要病害となっている。抵抗性品種は, 品種更 新が早いため定着しにくく, 薬剂防除では耐性菌の出 現が問題となっている。昨夏は稀にみる高温少雨の年 であり,これが抑制要因となり白さび病の発生は栽培 期間中には注とんど認められなかった。そこで，人為 的にこのような環境条件を与兄防除の可能性を検討し た。試験は, 白さび病の発生を調查して年次間の発病 差異を比較するとともに，挿し芽の高温処理による防 除効果を調べた。

1933 年は 4 月から 9 月まで, 1994年は 6 月から 9 月 まで新庄町および平群町の現地固場ならびに農試場内 で白さび病の発生を調査した。1993年は 7 月下旬まで 発病が高く推移し，8月以降は衰微したが，採花時に 病斑は残っていた。

1994年には上記の場所に当麻町を加えて調査した。 6 月には䍜病性品種で発病を認めたが， 7 月以降には 上位進展は全く認められず，採花時にも病斑は認めら れなかった。しかし，11月下旬の調査では，採花後放 置あるいは育苗中の苗で発生の認められた畨場があっ た。昨年の発病抑制には夏期の高温が影響したと思わ れ, 高温処理による防除の可能性が示唆された。

罹病葉を用いて冬胞子発芽の抑制に最も有効な温度 を調査した結果， $30^{\circ} \mathrm{C}$ 以上に 1 日以上遭遇させると冬 胞子の発芽が抑制された。罹病苗を用いて処理時間を 検討したところ， 1 日当たり $35^{\circ} \mathrm{Cを} 6$ 時間として， 2 日以上経過させると冬胞子の発芽が抑制された。20 (8 時間) $-35^{\circ} \mathrm{C}$ ( 6 時間 $)-15^{\circ} \mathrm{C}$ (10時間) の変 温管理では， 7 日間継続すると，汪とんどの罹病葉は 枯死・脱落し, 発病程度は低下して, 残存した冬胞子 も発芽しなかった。しかし, 高温処理後, $20^{\circ} \mathrm{C}$ に移し た苗は 2 週間後には新たな発病はなかったが， 3 週間 後に冬胞子堆の形成が起こり, 冬胞子も発芽した。

以上，苗の高温処理はキク白さび病の防除に有効で あるが，処理後の発病抑制についてさらに検討してい きたい。 


\section{カキうどんこ病の発病程度と 被害について}

\author{
島津 康・家村浩海 \\ （和歌山県果樹園芸試験場）
}

カキ5どんこ病は, 葉に発生し, 早期落葉を引き起 こして果実の肥大を㧕制するとされている。しかし， 果実に直接被害を与えないことから，経済栽培上の被 害評価を明確にできない場合も多い。そこで，5どん こ病の発病程度の違いが落葉, 果実生産に与える影響 について検討した。

カキ（品種：富有，41年生）ほ場で，1994年に生有 期間を通して，5どんこ病の防除を行わない区（無防 除区), 和歌山県の防除歷例にもとづいた防除区（通 常防除区)および防除回数を増やした区(濃密防除区) を設け，6月から10月にかけて発病状況を調査した。

これらの区で，10月27日に1樹10本の新梢をラベル し，11月30日まで 7 ～10日間隔で落葉状況を調査した。 収檴は11月21日と29日に行い, 1 回目の収檴時には果 皮色がカラーチャート指数 6 以上の果実を, 2 回目に は残りの果実を採取した。収檴果は樹ごとに個数, 重 量を調べた。また，8月と10月に発病程度の異なる葉 について, 光合成測定装置（島津製作所製，S P B H 2 ）を用いて光合成速度を測定した。

試験ほ場における5どんこ病の発生は 9 月上旬まで 少なく、その後增加して後期多発型となった。

10月下旬の処理区間の発病度は, 無防除区, 通常防 除区，濃度防除区で，それぞれ44，21，8であった。

落葉は11月中旬から始まり, 各試験区とも同様な推 移で，11月下旬にはほとんど落葉し，有意な差は認め られなかった。

1 回目の収檴時の収量割合は濃密防除区が最も高く, 通常防除区, 無防除区の順であり, 無防除区の果実は 着色が遅れる傾向にあった。1 果平均重は大きいもの から通常防除区，無防除区，濃密防除区の順であった。 しかし，いずれの調査も処理区間に有意な差はなかっ た。光合成速度は5どんこ病無発生の葉で高く, 甚発 生の葉で低い值を示し，その傾向は10月の測定時によ り䫒著であった。

以上のことから，5とんこ病の発病は葉の光合成速 度に影響するが，5どんこ病の発病程度が樹へ及ぼす 影響については, 生育後期に多発した場合, 落葉時期 の早晚，収嚄時期，収量に及ぼす影響は小さいものと 思われた。

\section{コンテナ栽培の豆苗で発生し} たPythium aphanidermatum

\section{による根腐病}

\author{
草杊畺一・岡田清嗣・*森田彰朗 \\ （大阪府立農林技術センター, \\ *北河内地域農業改良普及センター)
}

最近, エンドゥ（Pisum sativum L.）の奻苗を食 用とする「豆苗」のコンテナ栽培が行われているが, この豆苗栽培時に発生する根腐病が発生し問題となっ ている。通常, 豆は発砲スチロール製のコンテナ内の ウレタンマット上に播種後有苗されるが, 発芽前, 発 牙直後および出荷直前の各ステージで根が褐変して腐 敗，または地際茎部が水侵状になり，軟腐・腐敗する 症状が認められ、コンテナ全体の苗が腐敗した。罹病 組織から病原菌を分離したところ, 高い頻度で Pythium属菌が分離された。分離されたPythium属菌 は生育温度か3 $35-38^{\circ} \mathrm{C}$ で, 生育適温付近では非常に早 く生育する。分離菌は, コレステロール添加野菜シュー ス寒天培地（カコメ無塩野菜シュースを遠心分離して 上清を使用), およびSchmitthenner培地上で多数の 膨状遊走子を形成し，ペトリ水中で多数の遊走子を形 成した。また, 藏卵器は菌系に頂生し, 球形, 平滑, 内部に不充満性の卵胞子 1 個を形成した。蔵卵器の直 形は22-23cmで, 通常1 2個の蔵精器が付着してい る。藏精器は間生で, まれに頂生を認めた。本菌は, 上記形態的特徽からVan Der Plaats-Niterinkの分 類検索表に従ってPythium aphanidermatum (Edson) Fitzp.と同定された。エンドゥを曼すPythium属菌と しては, 苗立枯病の病原菌としてP.debaryanum Hess が報告されているがP.aphanidermatumは未記載であ り, 本病を, 豆苗の根腐病（エンドウ根腐病）とした い。

本病の感染経路について調査したところ, 種皮の白 い種子のものと褐色の種子が混しっており，この種皮 が褐色〜黒色に変色した種子からは, わずかに病原菌 が検出された。また，コンテナのスチロール内に侵入 している根を取り出し病原菌の検出を行ったところ， $5.2 \%$ の頻度で, 発病したコンテナでは $87 \%$ の高い頻 度で病原菌が検出された。以上のことから, 本病は, 出荷に用いたコンテナのスチロールに侵入した根, 污 染した種子により病原菌が施設に侵入，层染するもの と考えられる。 


\section{ハクサイ根こぶ病に対する 薬片の処理方法と石灰窒素 併用の効果}

\author{
前田和也・増田吉彦 \\ （和歌山県農業試験場）
}

和歌山県の紀北地域では, 県内の主要産地として, ハクサイ等の露地野菜を中心に生産振興が図られてき た。近年, ハクサイの年内どり作型で根こぶ病の発生 が増加し，産地では大きな問題となっている。その対 策として, 薬剂の種類と処理方法および石灰窒素の併 用による防除対策について検討した。

\section{試験方法}

試験は和歌山市岩橋のハクサイ根こぶ病污染固場に おいて実施した。品種はCR29で，セルトレーで育苗 した19日苗を 9 月27日に定植した。供試した薬剤は,

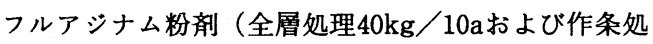
理 $20 \mathrm{~kg} / 10 \mathrm{a}$ ), フルスルファミド粉剤（全層処理 $30 \mathrm{k}$ $\mathrm{g} / 10 \mathrm{a}$ 及び作条処理 $15 \mathrm{~kg} / 10 \mathrm{a}$ ), PCNB粉剂（作条 処理 $12 \mathrm{~kg} / 10 \mathrm{a})$ であった。全層処理は 9 月20日に, 作条処理は 9 月 27 日の定植時に処理した。なお, 各区 に石灰窒素施用 $(120 \mathrm{~kg} / 10 \mathrm{a} ， 9$ 月 20 日全層処理） 区および無施用区を設けた。

処理面積は 1 区 $6 \mathrm{~m}^{2}$ で 2 反復とした。調査は 11 月 9 日に根部の根こぶ着生程度と八クサイの全重調査を 行った。

\section{結果および考察}

試験戋場の根こぶ病の発生は10月中旬に初発を認め, 11 月上旬には無処理区で発病株率 $100 \%$, 発病度 80 以 上と多発した。

薬剤の単用処理では, いずれの薬剤でも発病株率は $90 \%$ 以上と高かった。発病度は無処理区の $1 / 2$ 程度 に抑制され，収嚄重量も増加したものの十分な効果で はなかった。薬剤間や全層処理, 作条処理による差は 明確でなかった。

薬剤と石灰窒素併用による効果は, 発病株率が $80 \%$ 以上と高く, 発病度も薬剤の単用処理に比べて若干低 くなる傾向にあったが，䫒著なものではなかった。

以上の結果, 根こぶ病多発直場では, 薬剤処理と石 灰窒素を併用しても防除効果が十分でなく, 更に他の 防除手段との総合的な検討が必要と考兄られた。

\section{バーティシリウム菌に対する 微生物資材の効果}

\author{
加藤晋朗 \\ （愛知県農業総合試験場）
}

バーティシリウム菌による病害の防除には土㙥くん 蒸剤が使用されるが，土壤くん蒸剤は人体や環境に対 する悪影響が大きく，その使用量削減が求められてい る。そこで，市販微生物資材の発病抑制効果を陽熱処 理と組み合わせた場合も併せて検討した。

\section{試験方法}

試験 $1:$ 市販微生物資材の発病抑制効果 病原菌污 染土裹を用い, V S $-3470 \mathrm{~kg} / 10 \mathrm{a}$ とV S がん $30 \mathrm{~kg} / 10 \mathrm{a}$ 混用, オーレスG $120 \mathrm{~kg} / 10 \mathrm{a}$ ，ビコック $450 \mathrm{~kg} / 10 \mathrm{a}$, バイオ $20100 \mathrm{~kg} / 10 \mathrm{a}$, ビオモリタ $84 \mathrm{~kg} /$ $10 \mathrm{a}$ ，無施用の 6 区及び各徽生物資材（無施用含む） と稲わら $1 \mathrm{t} / 10 \mathrm{a}$ 併用の計12区を設けた。これにナス 苗を移植して半身萎ちょう病の発病抑制効果を検討し た $\left(0.18 \mathrm{~m}^{2}\right.$ コンテナ 8 株植, 3 反復)。

試験 2 : 微生物資材, 陽熱処理及びその組み合わせ 効果 試験 1 で効果の認められたV S - 34とVSあか きんの混用（稲わら併用），オーレスG（稲わら併用） について, 単独及び陽熱処理と組み合わせた場合の黄 化病の発病抑制効果を污染ほ場でハクサイを栽培して 検討した（1区12.7 $\mathrm{m}^{2} ， 2$ 反復)。

\section{結果及び考察}

試験 1 : 供試 5 資材はいずれも発病抑制効果が認め られ、この5ちV S-34とVSあかきんの混用，つい でオーレスGが優れた。また, 各微生物資材と稲わら の併用は発病抑制効果を高めた。しかし,これらの微 生物資材の効果はいずれの場合も発病始期を遅らせる ことにあるよらで, 初発後の進展は急激であった。

試験 $2 ： \mathrm{VS}-34$ とVS あかんの混用（非陽熱処 理）で発病抑制効果が認められたが，陽熱処理単独の 効果よりも明らかに劣った。また，陽熱処理後にV S -34, V Sあかきんを施用した場合，陽熱処理の効果 が高いためか，微生物資材の効果は判然としなかった。

以上の結果より, 今回供試した徽生物資材は, 単独 使用では実用上十分な効果は期待できないと判断され た。したがって，現時点では耕種的，物理的等を組み 合わせた総合的防除対策の一手段と考劣る。 


\section{養液栽培におけるシュンギク菌核 病（新称）の発病並びに発泡スチ ロール製パネルに付着した菌核に よるホウレンソウ株腐病の発生}

岡山健夫・松谷幸子・杉村輝彦

（奈良県農業試験場）

1993年12月, 天理市二階堂の養液栽培において収穫 間際のシュンギクの株が萎ちょう, 腐敗症状を呈して 枯死した。品種は中葉種で, 葉柄, 葉が侵され, 葉柄 は地ぎわ部が水浸状になって軟化腐敗した。被害株は 坪状に発生して倒伏した。被害を受けた葉柄基部は白 色綿状の菌系で覆われ, 腐敗部分に菌核の形成が認め られた。常法により，被害組織から菌を分離した結果， Sclerotinia属菌が分離され, 斜面培地で菌核および子 のう盤を形成した。菌そら片をシュンギクに接種した ところ, 同様の症状が現れ，キュウリ果実にも病原性 があった。本病をSclerotinia sclerotiorum (Libert) de Baryによるシュンギク菌核病としたい。この養液栽 培施設では, シュンギクのほかホウレンソウ, チンゲ ソサイを栽培しているが，これらには発生を認めなかっ た。

1994年10月, 養液栽培のプラントメーカーから発泡 スチロール製パネルについて病菌の調査依頼があった。 障害は千葉県下で発生し, 生産者はこのプラントを使っ て 3 年になり, 持ち込まれたパネルでホウレンソウを 栽培すると頻繁に萎ちょ5腐敗して枯死株が発生する とのことであった。発泡スチロールには表面に多数の 黒点があり, 実体顕微鏡で観察したところ, 小黒点は 菌核様の塊で，発泡スチロールの表面だけでなく，約 $1 \sim 2 \mathrm{~cm}$ 範囲の内部に食い込んで形成していた。 常法により小黒点を培養した結果, Rhizoctomia属菌が 分離された。ホウレンソウの幼苗に菌そう片を接種し たところ，株腐症状が再現された。再現株から同一菌 が再分離され, Rhizoctonia solaniによる株腐病と同定 した。発泡スチロールは使用年数の経過にともなって 陌間が生じ，この部分に菌核を形成するものと考えら れる。発泡スチロールの消毒にはケミクロンGによる 処理が行われているが，このようなパネル消毒には効 果が不十分であり，他の防除法を考案する必要がある。

\section{エライザ法によるグラジオラ ス球根の CMV保毒検定}

増田吉彦・前田和也 （和歌山県農業試験場）

グラジオラスに発生するウイルス病の病原としてキュ ウリモザイクウイルス（CMV)，インゲンマメ黄斑 モザイクウイルス（B Y MV)，タバコ論点ウイルス （T R S V) が報告されている。和歌山県において主 に発生が認められるのは，CMVおよびB Y MVであ る。特にCMVは発生が多く, 茎葉にモザイク症状を, 花弁に激しい斑入りを生じることから被害が大きい。 多発圑場では植付け球根の保毒率が高いことが主要因 と考えられた。そこで，エライザ法による球根のCM $\mathrm{V}$ 保毒検定法を検討した。

品種“ノバラックス”および“スピック＆スパン” の球根の側部を20〜 50mg切り取り, $3 \mathrm{ml}$ の摩砕液で 摩砕後, キムワイプで滤過し検定液とした。検定には 日本植物防疫協会製のCMVエライザキットを用い, 常法に従って行った。さらに，検定に用いた球根を切 断部にベノミル水和剂を秎衣したのち定植し，白色寒 冷紗被覆下で発芽させ，この発芽葉の100～300 mgを 用い, 同様にエライザ検定を行った。

“ノバラックス”では60株中, 発芽葉でCMVが 7 株検出され，このうち植付け球根の検定で 6 株が検出 された。“スピック＆スパン”では50株中発芽葉で20 株が，球根ではこれらすべてを含む21株で検出された。 なお, 非特異反応は両品種において球根, 発芽葉共に 認められなかった。

さらにサンプル量と反応の強さについて検討したと ころ, 約 $100 \mathrm{mg}$ の球根の切除片と $5 \mathrm{ml}$ の摩砕液を用い ると感染球根においてO.D.405nm值が1.0以上とな り, 判定が容易となった。

次に，葉での検定により CMV保毒の有無が明らか な株について，その子球と木子を掘り取り，20mg大 の木子から $3 \mathrm{~g}$ 大の子球まで大きさ別に20個を無作為 に抽出し，感染の有無をエライザ法によって検定した。 感染株由来の子球および木子のすべてでCMVが検出 された。また，非感染株では非特異反応は認められず， 外皮の存在も影響しなかった。

以上の結果, グラジオラスの CMV保毒検定は子球 の一部切除片あるいは同一株由来の木子を用いたエラ イザ法により可能であった。 
コラトップ®゚゚ックの葉いもち 対象 1 回施用による葉いもち・ 穂いもちの一貫防除の可能性

津田幹雄・太田 昊・近藤泰彦 加藤重博・田中治一・高日幸義 （三共 農業科学研）

投げ込み用イネいもち病防除剤コラトップ®パック は，極めて省力的な水面施用郕として上市された新製 剤である。本剤は葉いもち初発10 20日前に $10 \mathrm{a}$ 当た り10〜13袋（120～150ga.i.／10a）の施用で，コラトッ プ粒剤と同等の高い葉いもち防除効果を示す。今回, コラトップ囚パックの葉いもち対象 1 回施用による葉 いもち・穂いもちの一貫防除の可能性を, 各地の水田 で検討した。

\section{試験方法}

いもち病防除試験は，1993年度および1994年度の 2 年間に, 京都府福知山市, 滋賀県甲賀町および兵庫県 日高町を中心に実施した。

両年度ともに，施用日および施用量が防除効果に及 ぼす影響を検討するために，コラトップ®パックを葉 いもち初発時，10日前および20日前に，それぞれ10a 当たり10袋または13袋の割合で施用し, 葉いもち・穂 いもち一貫防除の可能性を, 対照薬剤（コラトップ® 粒剂, オリゼメート®粒剤）と比較した。

\section{結果および考察}

両年度ともに，葉いもち初発の10日前頃の 1 回施用 で, 地域によっては, 穂いもち対象施用区と同等の穗 いもちに対する高い防除効果を示し，一貫防除の可能 性が示唆された。特に, 穂いもちに対しては, 葉いも ち初発が出穂の30日前頃と重なる地域の固場での効果 が高かった。従って一貫防除の施用時期は葉いもち初 発が出穂30４0日前に重なるよら考慮した上で，葉い もち初発の10日前頃が適期と考光られた。

施用量については $10 \mathrm{a}$ 当たり 10 袋又は 13 袋施用で同 等の高い防除効果を示した。しかし，いもち病が多発 生の場合は, 13袋施用区の方が防除効果は安定してい た。

兵庫県日高町の試験水田は火山灰土壤であるために， これまでュラトップ粒剤のいもち病防除効果が低い とされてきたが，本試験ではコラトップ®パックおよ びュラトップ粒剤ともに高い防除効果を示した。

また，いずれの試験でも薬害は観察されなかった。

\section{ラッキョウ乾腐病菌のベノミ ル剤に対する耐性菌の発達経 過と代替抄による防除効果}

\author{
佐古 勇・吉田浩之*・遠山 明** \\ （鳥取県園芸試験場・ $*$ 鳥取県農産園芸課 \\ $* *$ 滋賀県立短大）
}

鳥取県では本病の防除のために植付け時に毎年 1 回 のベノミル剂による種球浸漬処理が実施されている。 本菌のベノル耐性菌は1978年にはじめて出現が確認 され，1979年度，1980年度にはそれぞれM I C 值6.25 ppm以下の感性菌は $50.6 \%, 31.3 \%, \mathrm{M}$ I C 值 100 ppm以上の耐性菌は $46.3 \% ， 68.7 \%$ あり，M I C值 の頻度分布は明確な 2 峰性を示していた。その後，耐 性菌は1993年度，1994年度にはそれぞれ97.1\%，100

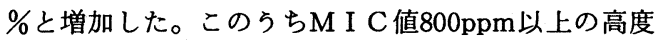
耐性菌は，1979年度，1980年度の時点ではそれぞれ 10.6\%，29.1\%であったが，湯の多くは発病株率 1 \%以下の低率であった。しかし，1993年度，1994年度 の高度耐性菌は，それぞれ $89.9 \% ， 99.1 \%$ と急敨に增 加すると同時に多発生注場が多くみられるよらになり， 発病株率は1.5〜33.0\%となった。

高度耐性菌保菌種球をべノミル剂で処理したときの 防除効果はきわめて劣ったが，プロクロラズ $25 \%$ 乳剤 200倍による種球処理は甚発生条件下で防除価88.4 高い発病抑制効果を示した。

さらに高度耐性菌の継代培養15年経過後，ならびに 高度耐性菌保菌種球のベノミル剤使用中止して 3 か年 間栽培後の再分離株には，耐性程度の低下はみられな かった。一方，プロクロラズ剤使用前のM I C 值はす べて6.25ppm以下であり，その大部分が3.12ppm以下 であった。また，プロクロラズ剤を 3 か年間使用して 栽培後のM I C 值の頻度分布に変動は認められなかっ た。

以上の結果から，ベノミル剂に対する高度耐性菌の 出現が乾腐病多発の一要因であり,ベノミル剤の使用 をしばらく中止しても耐性程度の低下は期待できない と考光られた。代替剤による本病防除にはプロクロラ ズ剤が有望と考学られた。 


\section{愛知県におけるベンズイミダ \\ ゾール系およびNーフェニル \\ カーバメート系薬剤複合耐性 \\ 灰色かび病菌の発生現況}

間下なぎさ・小出 隆子*

（愛知県農業総合試験場 $\cdot *$ 病害虫防除所）

愛知県では灰色かび病菌のベンズイミダゾール系薬 剂に対する耐性菌の発生が1975年から確認されていた。 1990年にベンズイミダゾール系薬棛に負の交差耐性を 持つNーフェニルカーバメート系薬剤が登録されたこ とから，両剤に対する耐性菌の発生状況を調査してき たので報告する。

\section{試験方法}

1991年から 4 か年, 県内の冬春トマト, ナス, キュ ウリで, 䍜病果からの組織分離により灰色かび病菌を 採集し、チオファネートメチル，Nーフェニルカーバ メート系薬剤各 5 ppm添加 P D A 培地で耐性検定を行っ た。

\section{結果及び考寮}

1991年のベンズイミダソール系薬剤耐性菌率は，キュ ウリで $92.2 \%$ とやや高く, トマトで $87.6 \%$, 尾張地域 のナスで52.5\%であった。

トマトでのベンズイミダソール系及びNーフェニル カーバメート系薬剤複合耐性菌（以下複合耐性菌）は 1992年に東三河地域で初発生した。尾張地域では発生 率は1993年の $36.1 \%$ から 1994 年には $71.2 \%$ と増加した。

キュウリでは複合耐性菌は1992年に初確認された。 このときの耐性菌率は5.2\%であったが，1993年は $88.5 \%$ 急增した。これは, キュウリは果実の生育が 早いため, 收檴期間中は䍜病部の除去など管理作業に 時間をさくことができず，薬剤防除に頼りがちとなる ことが主な原因と考えられる。

ナスでは複合耐性菌は1993年に尾張地域で初確認さ

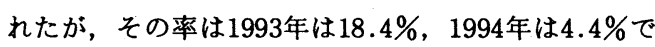
上昇はみられなかった。しかし，1994年の西三河地域 の複合耐性菌率は $45.2 \%$ ，地域により大きな差がみ られた。これは，尾張地域では管理作業が徹底してお り防除薬剤もスルフェン酸系剤等予防剤が中心である のに対し, 西三河地域ではNーフェニルカーバメート 系薬剤を含む剤が多用され，感受性菌が淘汰されたた めと考えられる。 